are the effect of restricted rooting upon early fruiting of the tomato, the use of electric light to hasten growth of cucumber seedlings, the use of soil heating for several crops, and the use of a surface rooting medium for tomatoes. Entomological investigations have included studies of rose thrips and onion thrips, and the use of a species of Scolothrips as a predatory control of red spider mite. Extensive mycological researches include the record, for the first time in Great Britain, of a leaf-spot of marguerite caused by the fungus Ramularia bellunensis. Physiological estimations of tomato seedlings have also been accomplished, and more general problems of soil nutrition have been studied.

\section{Lighting and Speed of Seeing}

A RECENT article (Brit. Eng. Export J., September) describes practical advances that have recently taken place in lighting. An interesting experiment is described which shows a relation between illumination and the speed of vision. The apparatus used was a heavy pendulum on which a test object was exposed to view when swinging between two screens. The speed of movement of the object was directly proportional to its distance from the pivot. At high illuminations, the test object could be seen when it was placed at the lowest point of the pendulum. At intensities not exceeding two foot candles, it was only visible when it was placed at a distance not exceeding a quarter of the way down, when its speed is only a quarter of what it is at the lowest point. After an increase to five foot candles the speed of seeing was increased by about 60 per cent.

\section{Model Chinese Junks}

A collection of large-scale models of Chinese junks, which is said to be unique, has been presented to the nation by Sir Frederick Maze, inspector-general of Chinese customs, for exhibition in the Seience Museum, South Kensington. The models, ten in number, were built in Hong-Kong or Shanghai by Chinese craftsmen, and are accurate replicas of these sailing craft in every detail, down to the shrines and household gods. They include examples with the magical eye on the prow. These boats, which are now giving place to steam in Chinese waters, and have also suffered many casualties during the present warfare, are of two main types, a northern and a southern. Except for details of rigging, they have not altered in principle over a prolonged period-at least a thousand years, and some authorities would hold for perhaps twice as long before that. Of these types, one has bluff bows and a flat bottom adapted for sailing in shallow waters. The other type has a sharp bow, with sheer lines and a deeper draught. Details of construction and rig in use among Chinese sailors at an early date are shown in these models, which did not appear in Western ships until a very much later period. Such, for example, are the watertight compartment, the battened sail used in yacht racing, lee boards of the keel and rudder types, and multiple sheets for independent handling of the upper and lower parts of the sails.

\section{Sternberg Astronomical Institute}

According to "Russia Today" Press Service, buildings for the Sternberg Astronomical Institute of Moscow will be commenced early next year in the vicinity of Butovo Station, one of the highest points on the outskirts of Moscow. The observatory, laboratory, mechanical workshops and blocks of flats to house the staff of the Institute will occupy a site of $14 \frac{1}{2}$ acres. The main part of the Institute's building will contain accommodation for research workers, lecture rooms, a library for 100,000 volumes and a storehouse for the 60,000 photographic negatives taken by the Observatory and by the Southern Astronomical Station in Tajikistan. Underground in the same block will be situated the time service with its astronomical clocks, and a gravimetric laboratory. A tower, to be erected over the main body of the building, is to be used for solar work. The removal of the Institute from Moscow is necessitated by the increasing vibration caused by traffic and the reflection of the city's electric lights in the sky, which interfere with astronomical observations.

\section{Centenary of the Greek Archæological Society}

Celebration of the centenary of the Greek Archæological Society began at Athens on October 23. The proceedings were opened in the Parthenon by the King of Greece, president of the Society, who delivered an address of welcome to the delegates and representatives of Greek and foreign universities and learned societies. Great Britain was represented by Mr. William Miller, of the British Academy, Mr. R. D. Barnett, of the Society for Hellenic Studies, and Mr. Gerald Mackworth Young, who was present on behalf of the Society of Antiquaries of London and the British School of Archaeology at Athens. The programme of the celebration, it is reported in The Times of October 24, includes excursions to Delphi, Eleusis and Epidaurus, the conferring of academic honours on distinguished archæologists, the laying of wreaths on the Cenotaph and the statue of the late King Constantine, a former president of the Society, the performance of the Electra of Sophocles and King Lear, an official banquet given by the Government, and a number of receptions.

\section{The Night Sky in November}

THE moon is full on November 7 at $22 \cdot 4^{\mathrm{h}}$ and new on November 22 at $0 \cdot 1^{\text {h }}$ U.T. On November 7, there will occur a total eclipse of the moon under favourable conditions-given fine weather-for observation in Great Britain. Contact of the umbra with the moon's limb at position angle $94^{\circ}$ from the north point, measured towards the east, occurs at $20^{\mathrm{h}} 41^{\mathrm{m}}$; total eclipse begins at $21^{\mathrm{h}} 45^{\mathrm{m}}$ and ends at $23^{\mathrm{h}} 8^{\mathrm{m}}$; the moon leaves the umbra at $0^{\mathrm{h}} 12^{\mathrm{m}}$ November 8 , the position angle of the last contact being $243^{\circ}$. Lunar conjunctions with the planets occur on November $1^{\mathrm{d}} 19^{\mathrm{h}}$ (Jupiter) : $5^{\mathrm{d}} 18^{\mathrm{h}}$ (Saturn) $18^{\mathrm{d}} 18^{\mathrm{h}}$ (Mars): $23^{\mathrm{d}} 21^{\mathrm{h}}$ (Mercury) and $29^{\mathrm{d}} 8^{\mathrm{h}}$ (Jupiter). There is a conjunction of Mercury and Venus on November 8, but both planets set very shortly after the sun. As the sky darkens, Jupiter is 